\title{
KIERKEGAARD'S ETHICS AS AN ANSWER TO HUMAN ALIENATION IN TECHNOCRATIC SOCIETY
}

\begin{abstract}
Kierkegaard is well-known for his noting tendencies of the present age which point in the direction of alienation. Tracking the course of Danish society's moral trajectory Kierkegaard considers recent developments in the direction of the outward, the superficiality of a mindset that craves entertainment and the latest fad. This hunger for entertainment, epitomized by the technical marvels of Tivoli, leaves man on the outside, a spectator unable to make important decisions. Whereas Kierkegaard's emphasis on the individual encountered in the critique of 'the crowd' can, and has been seen as an indirect critique of democracy (echoing Plato's objections) it is a concern with any potential threat to the integrity of the individual. Considering Kierkegaard in relation to other dominant voices of his time we find that he is concerned not only with the pastimes of his fellow citizens but more precisely with the lack of an overall idea of the true nature of human existence, a deficiency leaving them prey to technocratic encroachments.
\end{abstract}

Keywords: Kierkegaard, Technocratic Society, Alienation, Human Being.

\section{Kierkegaard and 1900 century Danish society}

It seems appropriate to ask why - if at all - Kierkegaard's words of concern regarding Danish society two centuries ago are still of interest to us today. If we were to try to sketch an ethics as such based on his warnings as well as the proposed solutions, what would it look like and in what ways would it be valid to hear in his words a forewarning of times to come? A thinker of enduring relevance, Kierkegaard detects in his time certain unfortunate tendencies and is able to relate these to central insights into human nature as such. A thinker ahead of his time he anticipates the corrosive effects of nihilism, and inspires later psychology i.e. in the case of Freud, depth psychology and our awareness of the subconscious. Central to his influence on later thinkers is his concern with the human self: how we human beings relate ourselves to the surrounding world and, vitally, how we relate to ourselves.

How this connects with the topic of this article will become clear when we consider to what extent the concern with the human self must be seen as the point of departure for Kierkegaard's critique of the tendency of certain technological developments of his time. Tendencies, which as it turns out play an even more dramatic role in our day [1]. But let us first turn to the sense of the importance of the role played by communication which seems to both underpin his critique and spell out part of a solution.

\section{The dangers of communication}

Considering Kierkegaard's apprehension with regard to the status of his 'present age' we find that it is specifically the status of the individual that concerns him. Certain developments within nineteenth century Danish society he sees as detrimental to the development of the individual. Kierkegaard comments on the general technical advances including the bustle of Tivoli where everyone is on display. Other Danish key figures of the time do so too, thus poet, playwright and literary critic, Heiberg, warns against the spectacular amusement park, seeing its success as a "failure of the contemporary public" [2, p. 22]. However, there are dangers graver than Tivoli. According to Kierkegaard, the individual is under pressure. Much of this pressure is due to developments in terms of the press. The inordinate amount of power wielded by those in charge of particularly one of the papers in Copenhagen at the time, Kierkegaard himself experienced personally in an attack which he to some extent brought upon himself when he chose to pick a fight with the satirical paper 'The Corsair' (Corsaren). The so-called 'Corsair affair' refers to a period, 1845-46, when Kierkegaard is ridiculed in the satirical paper. With its name taken from a French satirical paper 'Corsaren' should be seen

\footnotetext{
* ${ }^{1}$ Roman Kralik, ${ }^{2}$ Susanne Jakobsen Tinley

${ }^{1}$ Central European Research Institute of Soren Kierkegaard, Constantine the Philosopher University in Nitra, Faculty of Arts, Nitra, Slovakia

${ }^{2}$ University of Southern Denmark, Denmark

E-mail: rkralik@ukf.sk
} 
in that same tradition of satire originating in nineteenth century France. It was a great burden being singled out in this way and as a result to be given such excessive attention by the inhabitants of the walled 'market-town' as Kierkegaard referred to Copenhagen. The Corsair affair catapulted the Kierkegaardian authorship in an unforeseen direction, changing his intention that his latest work Concluding Unscientific Postscript would be the last from his hand. The event marks the beginning of his assault on journalism - the power of the press to decide public opinion is a real danger. Not just for the individual singled out for ridicule but in a more general sense it is a danger to the individual reader. "Personality has been abolished", writes Kierkegaard, and the "driving force behind impersonality: the press - and anonymity", he continues: "But the somebody who is nobody (and therefore has no responsibility) can put any error into circulation [...] and with the help of the most dreadfully disproportioned communications medium, that is terrible. And that this irresponsible error should then be taken up by the public which is again nobody! There is no one anywhere, and that is why there is error everywhere [...]" [3]. With the press then arrives the mass-audience and the resulting lack of responsibility feeds a misrelation in the form of an underdeveloped self.

\section{The individual}

What we find is that with Kierkegaard the all-important relationship to be considered is the relationship of the individual to himself. Kierkegaard has repeatedly been accused of focusing too singularly on the self-relation and thereby overlooking the relation of the individual to society. In order to understand what may appear as one-sidedness it helps to consider that for Kierkegaard and the tradition to which he can be said to belong, the endeavor to improve one's situation begins with oneself. He explains: "I am accused of causing young people to acquiesce in subjectivity. Maybe, for a moment. But how would it be possible to eliminate all these phantoms of objectivity such as the public, etc. except by stressing the category of the particular? Under the pretext of objectivity, the aim has been to sacrifice individualities altogether" [4]. Hence it seems the emphasis on the individual's relation to himself is appropriate when faced with the opposite tendency in society.

\section{Kierkegaard the Socratic}

Rather than attempting to sketch a Kierkegaardian ethics in a straightforward way in the terminology of contemporary ethics, considering his interest in the Greek tradition is often a good point of departure. The importance of the topic of communication seems a recurrent theme in both the self-understanding of this 'Socrates of Copenhagen' and in his critique of his age. Thus, the solution to the creation of mass-man appears to be the singling out of the individual.

Clearly the example of Socrates played a major role throughout Kierkegaard's authorship. The level of commitment becomes evident in his insistence on being accessible to his fellow Copenhageners, meeting them in the streets striking up conversations with individuals of all backgrounds. However, just as at the time of Socrates, Copenhagen society at large is not keen to see themselves and their ideals for what they really are. In a city where the prevailing mood, according to Kierkegaard, is one of fear and envy, his visibility as an effect of the Corsair affair changes the way he is able to interact with his fellow Copenhageners. The Socratic ideal concerns, in the words of Muench, an "awareness needed in order to avoid falling into the trap of imagining knowing more than one does, this "acute selfawareness" is what Kierkegaard seeks to provide to others [5, p. 29]. "In fact, he must himself be an accomplished master of this activity (he must uphold the Delphic injunction to know thyself) if he is to be able to help others to make similar discoveries about themselves and to introduce them into the rigors of a life that seeks to avoid that more disgraceful kind of ignorance in all its various manifestations" [5, p. 29].

\section{The role of the author}

Overall Kierkegaard's critique can be said to concern communication broadly. Related to the criticism of the press is his assessment of certain authors whose works fail live up to Kierkegaard's understanding of the role of the author. Among these was Hans Christian Andersen, the poet and author world famous for his fairytales and eight years Kierkegaard's senior. He singles out Andersen for criticism for having no life-view to offer his readers. It seems that Kierkegaard demands of the author that he remain true to himself even while the world around him changes. In the words of Lone Koldtoft: "It was not simply a review of the novel, but a personal attack on Andersen himself. Kierkegaard characterizes the novel's main character, Christian, as "a sniveler," "a little boy," and "a poor wretch," who is without strength of character, vain, responding only passively to the whims of his milieu." Koldtoft quotes Kierkegaard: "The same joyless battle Andersen himself fights in life now repeats itself in poetry" [6, p. 14]. To Kierkegaard there is a subtle but important difference in the author's speaking from the position of a 'life-view' as opposed to simply allowing his own personality to get in the way of the reader's understanding. However, while Kierkegaard spends much time critiquing those around him, he in turn spends even more of his time considering his own approach, concerned with the success of the method, balancing his pseudonymous with the upbuilding, Christian part of his authorship. With the author lies the power to speak in a very personal way to his reader - a task which Kierkegaard as an author surely took upon himself [7].

\section{Freedom of human being}

In his work, Kierkegaard strives to show how one should live. He utterly rejects any utilitarian motives on the side 
of man, such as expediency, self-interest calculation, or preferential relationships, whether this be in relation to God or to one's neighbor. The same holds true for faith itself. Faith requires that one's actions are conducted with a pure heart and a desire for good. Faith itself must be interconnected with deeds. Whenever faith is detached from deeds (corresponding to faith) and/or it becomes opportunistic or driven by fear, doubts start to emerge.

In addition to wanting to act and acting on the basis of faith, man must also think on the basis of faith. Kierkegaard tries hard to lead man by means of indirect questions and examples to searching for truth. What is the motivation of man's actions? Why is he acting the way he is acting? What does he truly desire? What will be the means to the desired end?

Kierkegaard is a beautiful example to us of the fact that, on account of his wealth and comfort (derived from technology), man had ceased to experience joy in life and peace in his soul. Kierkegaard uses the following example to contrast wealth with the ability to see the stars.

When the well-to-do person is riding comfortably in his carriage on a dark but starlit night and has the lanterns lit-well, then he feels safe and fears no difficulty; he himself is carrying along the light, and it is not dark right around him. But just because he has the lanterns lit and has a strong light close by, he cannot see the stars at all. His lanterns darken the stars, which the poor peasant, who drives without lanterns, can see gloriously in the dark but starlit night. The deceived live this way in temporality: busily engaged with the necessities of life, they are either too busy to gain the extensive view, or in their prosperity and pleasant days they have, as it were, the lanterns lit, have everything around them and close to them so safe, so bright, so comfortable - but the extensive view is lacking, the extensive view, the view of the stars [8, p. 310].

So, the human being now faces an acute choice: to own, or to experience and to be. The choice to own wealth brings him stress, restlessness, a constant psychological pressure to cope with ever changing circumstances, to always be better in order to withstand the ever-increasing demands of a highly competitive environment. Resulting from the human choice to always achieve better results (and to always own more) is his loneliness [9].

Another reason for man's loneliness is that he is willing to act unethically in order to gain more wealth and/or career advancement. Achieving the set goals becomes the highest priority for humans, no matter what the costs are. Human individuals no longer care about the means that are used in achieving the desired goals. This can clearly be seen in bicycle racing with the seemingly omnipresent "technical doping'.

The athletes are by far not the only ones who have to prove their abilities under undue pressure. Quality was replaced by quantity and a desire for a quick success. Achieving one's goal assumes the highest priority. Kierkegaard writes about this situation with clarity in his work Purity of Heart:

And now the means that you use. What means do you use to perform your work; is the means just as important to you as the end, just exactly as important? If not, you cannot possibly will one thing; in that case the indefensible, the irresponsible, the self-serving, the heterogeneous means enters in, disturbing and defiling. Eternally understood, the means is one thing, the end is one thing, the means and the end are one and the same. There is only one end: the good in truth, and only one means: to will to use only the means that in truth is the good means- but the good in truth is indeed the end. Temporally and mundanely the two are separated and the end is considered more important than the means; the end is considered primary. It is required of the one striving that he achieve the end; he may be less scrupulous about the means. But this is not the case, and to have an end in this way is an ungodly impatience. In the eternal sense, the relation between end and means is rather the reverse. If a person sets himself an end for his striving here in life and does not achieve it, he may possibly be altogether without guilt in the eternal sense, yes, is even to be praised. After all, he can be prevented by death or by adversities that are not under his control; in that case, he is entirely without guilt. He can even be prevented from achieving the end by refusing to use means other than what is admissible according to eternity's understanding, that is, by renouncing the impatience of passion and the devices of sagacity-in that case he is even to be praised. Thus, he is not eternally responsible for achieving his end in temporality, but he is unconditionally eternally responsible for which means he uses [8, p. 141].

Human individuals living in the present, technocratic world desire to own more and to be successful at all costs. They constantly compare themselves to others, they never seem content and their only goal seems to be a comfortable, secure life filled with pleasures. The driving force of one's actions, therefore, becomes one's reward and benefit. Any selflimitations, self-renunciation, or any austerity measures are sternly rejected and maximum benefit is pursued at all costs. Kierkegaard, on the other hand, wanted to remind human individuals of the unavoidable need to understand oneself, one's own existence, including one's own weakness (and insignificance) before God. Kierkegaard did not believe that man would become better or happier on the basis of scientific or technological advances. He was rather skeptical to the fruits of technological progress which had promised to fulfill both, the social and the individual needs and expectations of people. He did not believe in institutions, progress; he had no trust in people who, after they had gained an office, they clung to it, trying to hold on to it regardless the costs because they were convinced it (the office they held) would secure them a comfortable life. 
What is the situation today? With the help of science and technology, man can achieve the impossible, yet one is unable to solve one's intrapersonal and interpersonal conflicts, looming at every corner. Human beings experience more, not less anxiety and despair, striving desperately to overcome their inner suffering. The root cause that Kierkegaard saw behind this situation was the crisis of relationship between man and God. The human individual has ceased to reflect intellectually about the meaning of life and instead spends countless hours playing computer games or absorbing senseless media contents delivered by contemporary reality shows. It seems as if man had ceased to search for a meaning of one's actions, existence, even of one's own self. Human being has stopped to search for the meaning of life on Earth. These questions bring discomfort to man, they bring about an inner pain (or, perhaps, even anguish), and so one tries to push them away from one's life-horizon. The contemporary man has lost faith in good and no longer seems to enjoy the natural inclination to do good. Kierkegaard's Purity of Heart is thus intended to be a sobering mirror to those who live in self-deception, as well as an enticement of hope to those suffering from despair.

Kierkegaard saw the problem faced by humans living in a technocratic society, a society that allows each individual to focus only on one's own need. The aim ought to be the fulfillment of one's greater purpose. Kierkegaard therefore requires that everyone love others and help them find their way to the good. Kierkegaard thought that the problem of European Christianity as a whole was the inclination of people to subordinate everything to their own welfare and their unwillingness to suffer and to sacrifice anything for the sake of others. They forgot to follow the example of the founder of Christian ethics - Jesus Christ. The true freedom of man lies not in technocracy, but in free decision making.

\section{Kierkegaard's Legacy for our Age}

Relating Kierkegaard's criticism of the press of his time to our situation today we find it is even more relevant now. According to Katharine Viner, Editor.in Chief of the Guardian, it is not that nobody cares about the truth any longer. She writes in her article 'How technology disrupted the truth' that rather it is that '[s]ocial media has swallowed the truth' and how the nature of certain websites cause an entirely fictional story to climb to the top of the currently trending stories to look like an established fact. She continues: "Twenty-five years after the first website went online, it is clear that we are living through a period of dizzying transition. For 500 years after Gutenberg, the dominant form of information was the printed page [...]" a format "that encouraged readers to believe in stable and settled truths" as opposed to the situation today where we are "caught in a series of confusing battles between opposing forces: between truth and falsehood, fact and rumor [...]between an informed public and a misguided mob" [10]. For Kierkegaard, the truth of main importance was to be found in the relationship of the individual to himself, in taking responsibility for one's actions. Alienation in its 'deeper form' is in Kierkegaard's opinion, as pointed out by Malantschuk, "rooted in spiritual factors" and it requires a "change from within" [11, p. 14] if Mass-man is to avoid being influenced by external powers. Such a change would require that each man become a 'single individual' and in turn requires that those in a position to understand this take care to help others into a position to discover the same for themselves. Hence the critique of a brilliant, wellknown author such as Andersen who was indeed able to influence a large audience but, in Kierkegaard's opinion failed to make use of this position.

Nowadays man experiences loneliness. One reason for this is the constant increase of his desire to own things. Man in technocratic society is not satisfied with his achievements and is under the pressure of society, in particular consumerism. Humans have become dependent on others and subordinated their relationships, thoughts and actions to the needs of modern society. Kierkegaard's ethics offers a solution. This solution lies in becoming an individual and in searching and finding selfless priorities.

\section{Conclusion}

Kierkegaard was able to play the role of Socrates in relation to his city. His works continue to play a role today when read and appreciated by that rare reader who is willing to take the time to first understand and then attempt to consider what they read in relation to their own life. Kierkegaard attempts to make out of his readers 'single individuals' who are able to withstand the pressure of external pressure. Perhaps, just as Kierkegaard lets his pseudonym Anti-Climacus repeatedly call out the name of his hero: "Socrates, Socrates, Socrates!" saying that what the world needs is not a republic, a new social order or a new religion, rather it "is a Socrates" - some "ironic-ethical correction" [12, p. 92], we could say today that what our modern times need might be to revisit Kierkegaard's thoughts on the importance of the single individual. Just as Socrates denies that he, the wisest man, knows anything, Kierkegaard denies being a Christian [13, p. 99]. In doing so he attempts to emphasize the efforts implied in considering oneself a Christian in a meaningful sense. His function is to hold a mirror for his time to reflect itself in so as to discover its shortcomings - a function which will probably never be met with much enthusiasm regardless of the age in question.

The problem of modern individuals is their fear of everything unknown, of uncertainty, the fear of losing what one gained.

Kierkegaard's ethics offers solutions to overcoming human alienation:

a) orientation towards one's neighbor living next to us, 
b) emphasizing non-preferential love to others,

c) ceasing to focus exclusively on one's own goals and intentions, and instead being there for others, helping them to find their own way to the good,

d) willingness to accept suffering, injustice and humiliation. Kierkegaard did not see the optimal future of mankind in the improvement of its technocratic attributes; he rather relied on human inwardness, on a passionate determination to seek a positive relationship with others and with God. Kierkegaard's ethics emphasizes human relationship and the love of neighbor. As long as the increasingly sophisticated use of technology remains mankind's highest interest, human alienation will only deepen.

\section{References:}

[1] Even if our current liberal democracies "embody the best socio-economic system and human political governance" that humanity has been able to generate, "this celebrated 'socio-political contract' moves dangerously close to the abyss of the next totalitarianism, stemming from unchecked consumerism and media manipulation,” as Valco incisively points out. VALCO, M.: Rethinking the Role of Kierkegaard's 'Authentic Individual' in Liberal Capitalist Democracies Today, European J. of Science and Theology, vol. 11, No. 5, 2015, 129-139. ISSN 1841-0464.

[2] PATTISON, G.: Poor Paris!: Kierkegaard's Critique of the Spectacular city. Kierkegaard Studies. CAPPELORN, N. J., TOLSTRUP, C. (eds.), Berlin - New York : Walter de Gruyter, 1999. ISBN 978-3-11-176669-0.

[3] KIERKEGAARD, S.: Pap. VIII A 540. In Peter Andreas Heiberg, Victor Kuhr and Einer Torsting (eds.). Soren Kierkegaards Papirer. Copenhagen : Gyldendal, 1909-1948; expanded by Niels Thulstrup. Copenhagen : Gyldendal, 1968-78.

[4] KIERKEGAARD, S.: Pap. VIII A 8. In Peter Andreas Heiberg, Victor Kuhr and Einer Torsting (eds.). Soren Kierkegaards Papirer. Copenhagen: Gyldendal, 1909-1948; expanded by Niels Thulstrup. Copenhagen: Gyldendal, 1968-78.

[5] MUENCH, P.: Kierkegaard's Socratic Task. University of Pittsburgh. 2006. Ph.D. Dissertation. Available online: http://www. sorenkierkegaard.nl/artikelen/Engels/172.\%20Muench_Kierkegaard_socratic_task.pdf.

[6] KOLDTOFT, L.: 'Hans Christian Andersen: Andersen was Just an Excuse'. Kierkegaard and his Danish Contemporaries: Literature, Drama, and Aesthetics. Stewart, Jon Bartley, (ed.), Ashgate Publishing, Ltd. 2009, 1-31. ISBN 978-0754668749.

[7] For next inspiration compare to: DEBNAR, M.: The Disappearance of the Author and Meaning Making (in Slovak), World Literature Studies, vol. 25, No. 3, 2016. ISSN 1337-9690.

[8] KIERKEGAARD, S.: Upbuilding Discourses in Various Spirit. Princeton : Princeton University Press, 1993. ISBN 0-691-03274-2.

[9] For more on this topic, see: PAVLIKOVA, M.: Despair and Alienation of Modern Man in Society. European J. of Science and Theology, vol. 11, No. 3, 2015, 191-200. ISSN 1841-0464; PAVLIKOVA, M.: The Concept of Anxiety and its Reflection in Auden's work 'the Age of Anxiety. European J. of Science and Theology, vol. 12, No. 4, 2016, 111-119. ISSN 1841-0464; JUROVA, J.: On Etzioni's Concept of a Responsive Community. European J. of Science and Theology, vol. 12, No. 1, 2016, 71-80. ISSN 1841-0464; KONDRLA, P.: Apophatic Theology, Philosophy of Dialogue and Communication Perspectives. European J. of Science and Theology, vol. 12, No. 1, 2016, 117-128. ISSN 1841-0464; STUR, M.: Responsibility and Sensus Communis at Unamuno's, Ortega y Gasset's and Heidegger's Work. XLinguae, vol. 4, No. 4, 2011, 30-39. ISSN 1337-8384.

[10] VINER, K.: 2016, https://www.theguardian.com/media/2016/jul/12/how-technology-disrupted-the-truth

[11] MALANTSCHUK, G.: The Controversial Kierkegaard. Waterloo : Wilfrid Laurier University Press, 1980, ISBN 0-88920-093-9.

[12] KIERKEGAARD, S.: Sickness unto Death. Princeton : Princeton University Press, 1980. ISBN 0-691-07247-7.

[13] Valco highlights this fact commenting on Kierkegaard's The Sickness unto Death, pointing out that in this work the Danish author evoked “'idealized Christianity,' with which Kierkegaard does not dare to identify himself." VALCO, M.: Kierkegaard's 'Sickness unto Death' as a Resource in our Search for Personal Authenticity. European J. of Science and Theology, vol. 12, No. 1, 2016, 97-105. ISSN 1841-0464. 